\title{
PENGEMBANGAN MEDIA PEMBELAJARAN PREZI PADA MATA PELAJARAN MEMBUAT POLA DI SMK AWAL KARYA PEMBANGUNAN GALANG
}

\author{
Surani dan Dina Ampera \\ (Guru SMK Pemda Lubuk Pakam dan Dosen PKK-FT Unimed)
}

\begin{abstract}
ABSTRAK
Penelitian ini bertujuan untuk: 1) mengembangkan desain media pembelajaran prezi pada mata pelajaran membuat pola dan 2) mengetahui kelayakan atau efektivitas desai media pembelajaran prezi pada mata pelajaran membuat pola di SMK Awal Karya Pembangunan Galang. Serta media yang layak dan dapat digunakan sebagai pengembangan media pembelajaran baru yang membantu siswa dalam mempelajari mata pelajaran membuat pola. Metode penelitian yang digunakan dalam peneltian ini adalah metode Research and Development (R\&D). Dengan menggunakan tahap atau prosedur yang sudah diadaptasi yang meliputi: Potensi dan masalah, pengumpulan data, desain media dan uji coba. Subjek uji coba penelitian ini adalah 56 siswa kelas X SMK Awal Karya Pembangunan Galang. Desain uji coba ada dua tahap yaitu: uji coba (tahap validasi) dan uji coba produk. Instrumen pengumpulan data menggunakan angket, angket analisis kebutuhan, validator dan angket efektivitas meliputi skala penilaian dengan taknik analisis data menggunakan skala likert. Hasil penelitian menunjukkan bahwa desain media pembelajaran prezi pada mata pelajaran membuat pola ini berhasil dikembangkan melalui beberpa tahapan, yaitu 1) hasil penilaian ahli materi dengan skor $83 \%$ dengan kriteria baik dan hasil penilaian ahli media dengan skor $87,14 \%$ dengan kriteria sangat baik, 2) hasil penilaian uji coba kelompok: uji coba kelompok kecil dengan skor 63,3\% , uji coba kelompok sedang dengan skor 79,25\% dengan kriteria setuju, dan uji coba kelompok besar atau lapangan 89,25 dengan kriteria sangat setuju, 3) uji efektivitas siswa dengan skor rata-rata 89,25\% dengan kriteria sangat setuju dan uji efektivitas guru dengan skor rata-rata 93,33\% dengan kriteria sangat setuju. Dengan demikian, desain media pembelajaran prezi pada mata pelajaran membuat pola dianggap layak untuk dijadikan desain media pembelajaran.
\end{abstract}

\section{Kata Kunci: Pengembangan, Media Prezi, Efektivitas Media Prezi, Mata Pelajaran Membuat Pola}

\section{PENDAHULUAN}

Pendidikan merupakan salah satu aspek yang penting dalam kehidupan masyarakat dan pembangunan nasional dalam menciptakan sumberdaya manusia. Pendidikan melibatkan kegiatan belajar dan proses pembelajaran. Pendidikan merupakan suatu hubungan yang terjadi antara pendidik (guru) dan peserta didik (siswa).

Pendidikan kejuruan adalah bagian terpadu dari sistem pendidikan nasional yang mempersiapkan siswa menjadi anggota masyarakat yang memiliki kemampuan mengadakan hubungan timbal balik secara kreatif dan produktif dengan lingkungan sosial, budaya, ekonomi dan teknologi serta memiliki pengetahuan dan keterampilan kejuruan yang sesuai dengan persyaratan berbagai lapangan kerja atau menciptakan kesempatan kerja.

SMK Awal Karya Pembangunan (AKP) merupakan salah satu lembaga pendidikan kejuruan yang mengembangkan Kurikulum Tingkat Satuan Pendidikan. Pada Program Studi Tata Busana siswa mempelajari beberapa mata pelajaran kompetensi kejuruan yang menekankan pada pencapaian keterampilan. Salah satunya adalah mata pelajaran membuat pola di SMK Awal Karya Pembangunan merupakan pelajaran praktek yang dilaksanakan dikelas $\mathrm{X}$.

Dalam proses pembelajaran sangat dibutuhkan tiga hal penting yaitu materi pembelajaran, proses pembelajaran, dan hasil pembelajarannya. Dalam pelaksanaan proses belajar mengajar, ditunjang oleh 
pengetahuan, sikap, dan keterampilan. Maka antara kesejahteraan dan keterdidikan serta keterampilan SDM hingga mampu memanfaatkan teknologi, memiliki korelasi yang sangat erat.

Permasalahannya adalah bagaimana memproduksi serta memanfaatkan teknologi mutakhir media pembelajaran agar dapat digunakan dalam proses pembelajaran sehingga perencanaan pembelajaran tidak lagi konvensional. Pembelajaran bermedia biasanya dilakukan oleh seorang ahli dalam proses pengembangan pembelajaran. Proses penggunaan yang digunakan adalah proses pengembangan yang sistematik dan bukan sekedar pendekatan kepada siswa.

Berdasarkan observasi 22 Maret 2016 yang dilakukan penulis di sekolah SMK Awal Karya Pembangunan Galang jurusan Tata Busana pada mata pelajaran produktif pembuatan pola yaitu konstruksi pola dengan Ibu Iryani. Proses pembelajaran membuat pola menggunakan media power point sederhana menggunakan LCD dan papan tulis, spidol, dan buku pegangan guru dan sebagian besar masih dengan manual yaitu guru menggambar langkah-langkah membuat pola di papan tulis kemudian mendemonstrasikannya kepada siswa sehingga waktu yang digunakan terlalu lama. Sebagian siswa menganggap membuat pola itu pelajaran yang sulit dan menjenuhkan. Mendapati kondisi siswa yang perhatiannya tidak terfokus pada materi. Kondisi seperti ini membuat siswa mencapai hasil belajar yang diharapkan tidak maksimal. Situasi seperti ini tidak lepas dari semua komponen pendukung proses pembelajaran dikelas yaitu siswa, guru, dan media pembelajaran serta waktu pembelajaran. Berperannya komponen tersebut memungkinkan tercapainya pembelajaran yang efektif didalam kelas salahsatunya media pembelajaran yang ada pada dasarnya merupakan suatu sarana untuk menyampaikan pesan ataupun informasi agar dapat diterima dengan baik bahkan menarik.

Pemilihan media pembelajaran yang tepat dapat ikut berpengaruh dalam mewujudkan tercapainya tujuan pembelajaran. Pemanfaatan media yang tepat dan menarik dapat membantu dalam menciptakan situasi pembelajaran yang bersifat interaktif dengan melibatkan siswa didalamnya. Peran media pembelajaran yang berbasis multimedia memiliki potensi besar untuk merangsang siswa agar dapat merespon positif materi pembelajaran yang disampaikan.

Media pembelajaran yang berbasis komputer dapat dibuat dengan bantuan perangkat lunak (software). Salah satu perangkat lunak yang dapat digunakan untuk mengembangkan media pembelajaran adalah Prezi. Prezi adalah sebuah media pembelajaran yang dapat membantu guru untuk menyampaikan pesan yang kompleks menjadi menarik dengan cara yang dinamis. Media ini disertai dengan tema yang lebih bervariasi, juga menarik ketika dalam mode presentasi dengan menggunakan teknologi ZUI (Zooming User Interface), pengguna dapat memperbesar dan memperkecil tampilan frame dalam presentasi. Sehingga siswa termotivasi dalam proses pembelajaran.

Rumusan masalah penelitian ini adalah bagaimanakah pengembangan media pembelajaran membuat pola berbasis multimedia menggunakan Prezi pada mata pelajaran Membuat Pola kelas X SMK Awal Karya Pembangunan Galang? dan bagaimanakah efektifitas produk multimedia pembelajaran mata pelajaran Membuat Pola kelas X SMK Awal Karya Pembangunan?

Manfaat yang diharapkan dalam penelitian ini adalah Siswa 1) Memperkaya ilmu pengetahuan dalam bidang pengembangan produk Multimedia Pembelajaran terutama pada mata pelajaran Membuat Pola. 2) Membantu siswa untuk fokus dalam pembelajaran Membuat Pola. 3) Membantu siswa dalam mempelajari materi Membuat Pola. 4) Membangkitkan minat penelitian lanjutan untuk menkaji pengembangan multimedia pembelajaran Membuat Pola sesuai dengan kebutuhan. Guru bidang studi: 1) Meningkatkan proses pembelajaran yang lebih baik sehingga dapat membantu siswa untuk lebih mengoptimalkan potensi. 2) Membantu guru dalam proses mengajar agar siswa lebih tertarik lagi dalam proses belajar. Dan bagi peniliti yaitu peneliti ini bermaksud untuk 
mengembangkan suatu media pembelajaran yang dapat digunakan untuk menyajikan pesan-pesan intruksional kepada siswa agar tujuan pembelajaran dapat tercapai dengan baik. Dengan pengertian pelajar dapat memahami dan mengerti apa yang menjadi isi dan tujuan dari mata pelajaran membuat pola.

\section{KAJIAN TEORI}

Sanaky (2013) mengatakan media pembelajaran adalah sarana atau alat bantu pendidikan yang dapat digunakan sebagai perantara dalam proses pembelajaran untuk mempertinggi efektifitas dan efisiensi dalam mencapai tujuan pengajaran. Dan menurut Arsyad (2013) media pembelajaran adalah media pembelajaran adalah perantara yang membawa pesan atau informasi betujuan instruksional atau mengandung maksudmaksud pengajaran antara sumber dan penerima.

Arsyad (2011) mengemukakan bahwa pemakaian media pembelajaran dalam proses belajar mengajar dapat membangkitkan keinginan dan minat yang baru, membangkitkan motivasi dan rangsangan kegiatan belajar, dan bahkan membawa pengaruh-pengaruh psikologis terhadap siswa.

Maswin (2010), mengemukakan bahwa multimedia merupakan perpaduan antara media atau format file yang berupa teks, gambar (vektor atau bitmap), grafik, sound, animasi, video interaksi dan lain-lain, sedangkan dari Wikipedia Indonesia, Ensiklopedia berbahasa Indonesia multimeda adalah penggunaan komputer untuk menyajikan dan menggabungkan teks, suara, gambar, animasi, video dengan alat bantuan (tool) dan koneksi (link) sehingga pengguna dapat bernavigasi, berinteraksi, berkarya, dan berkomunikasi.

Prezi pada awalnya dikembangkan oleh arsitek Hungaria bernama Adam Somlai-Fischer sebagai alat visualisasi arsitektur. Misi yang dinyatakan oleh Prezi adalah untuk "membuat berbagi ide menjadi lebih menarik", dan Prezi sengaja dibuat untuk menjadi alat untuk mengembangkan dan berbagi ide dalam bentuk visual yang bersifat naratif.
Embi (2011) mengemukakan persembahan melalui Prezi dibina pada "kanvas" dan bukannya slide. Ini memudahkan penyampai untuk memberi tumpuan terhadap penggabungan teks, gambar dan multimedia. Item-item diatas kanvas boleh diheret, disengetkan dan dizoom agar lebih menarik.

Menurut Harvey dan Barringer (2014), Prezi adalah sebuah presentasi yang dapat membantu anda untuk menyampaikan pesan yang kompleks menjadi menarik dengan cara yang dinamis. Prezi juga merupakan sebuah software presentasi perangkat lunak "berbasis flash" dan memberi kebebasan pada pengguna untuk membuat sebuah presentasi yang dnamis yang terlihat berbeda dengan slide show powerpoint pada umumnya.

Aplikasi multimedia ini dapat digunakan dalam proses pembelajaran. Karena tampilannya yang menarik, dengan kata lain multimedia pembelajaran berguna untuk menyalurkan pesan (pengetahuan, keterampilan, dan sikap) serta dapat merangsang pilihan, perasaan, perhatian, dan kemauan siswa sehingga secara sengaja proses belajar terjadi, bertujuan, dan terkendali. Dengan ini juga dapat membantu guru untuk mendesain pembelajaran secara kreatif. Selain ditinjau dari manfaat media, multimedia ini memungkinkan siswa untuk berfikir secara aktif sehingga membangun minat dan motivasi dalam belajar. Dalam penilitian ini pemilihan media dilihat kesesuaiannya dengan materi pembelajaran, karena pemilihan materi berpengaruh terhadap kualitas tampilan.

Menurut Pratiwi, (2001), pola dasar adalah kutipan bentuk badan manusia yang asli atau pola yang belum diubah. Menurut Latifah (2013), pola busana merupakan potongan-potongan kertas yang merupakan bentuk bagian-bagian busana atau produk jahit-menjahit. Pola dibuat dengan menggunakan ukuran badan seseorang yang dibuatkan pola atau menggunakan ukuran standart. Pola yang dibuat pertama kali merupakan pola dasar yang merupakan kutipan bentuk badan yang asli atau belum mengalami perubahan. 
Menurut Ernawati, (2008) berdasarkan teknik pembuatannya pola dasar yaitu teknik drapping, teknik konstruksi, pola dasar. Berdasarkan bagiannya pola dasar terbagi tiga yaitu 1) pola dasar badan atas, 2) pola dasar badan bawah, dan 3) pola lengan.

Pada penelitian ini hanya pada bagian lengan. Dimana setelah mengetahui pola dasar lengan, dengan mengacu pada pola dasar dapat mengubah atau mengembangkannya sesuai dengan kebutuhan. Dalam pembuatannya harus menyesuaikan bentuk lengan terhadap model busana.

Menurut Poespo (2000), lengan adalah bagian komponen busana yang menutupi semua atau sebagian lengan. Penampilan lengan ditentukan oleh posisi lubang lengan dan jahitan bawah lengan, penambahan pada segala bagian lengan, serta keliman lengan atau mansetnya. Oleh karena lengan sering bergerak, maka lengan baju yang dirancang harus memberi cukup ruangan pula untuk bergerak. Simon (2008), mengatakan lengan merupakan bagian yang penting dari desain pakaian untuk tubuh bagian atas dan merupakan salah satu aspek yang dari desain. Lengan memiliki fungsi untuk melindungi pemakai dengan menutupi lengan pemakai. Macam-macam model pola lengan yaitu lengan suai, poff, kop, tulip, reglan, setali.

\section{METODOLOGI PENELITIAN}

Penelitian ini merupakan penelitian dan pengembangan (Research and Development) media pembelajaran, khususnya berupa pembelajaran melalui bahan ajar berbasis multimedia untuk mata pelajaran Membuat Pola. Maksudnya, merupakan pengembangan dari bahan ajar dalam bentuk lain, yang sifatnya melengkapi bahan ajar yang sudah ada.

Subjek penelitian adalah kelas $\mathrm{X}$ SMK Awal Karya Pembangunan Galang berjumlah 56 siswa. Objek penelitiannya yaitu produk media pembelajaran prezi pada mata pelajaran membuat pola.

Langkah-langkah penelitian dan pengembangan yang digunakan adalah mengadopsi dari tahap yang dikemukakan oleh Sugiyono (2014) dan melakukan perubahan pada tahap pengembangan media. Prosedur penelitian adalah serangkaian kegiatan yang dilaksanakan oleh peneliti secara teratur dan sistematis untuk mencapai tujuan penelitian.

Adapun prosedur penerapan $R \& D$ yang digunakan dalam penelitian pada mata pelajaran membuat pola: 1) potensi dan masalah, 2) pengumpulan data, 3) desain penelitian, 4) validasi ahli, 5) uji coba kelompok kecil dan revisi, 6) uji coba kelompok sedang dan revisi, 7) uji coba kelompok besar, dan 8) produk akhir.

Instrumen yang digunakan pada penelitian ini yaitu Media Pembelajaran Membuat Pola Berbasis Multimedia, materi Membuat Pola Macam-Macam Lengan dengan menggunakan Angket (Kuesioner).

Angket/kuesioner yang digunakan dalam penelitian ini berupa 1) angket analisis kebutuhan siswa dan guru 2) angket validator yaitu ahli media dan ahli materi untuk mengetahui kelayakan media membuat pola macam-macam lengan pada mata pelajaran membuat pola 3) angket efektivitas media untuk siswa dan guru. Kisi-kisi instrumen penelitian tersebut dapat dilihat pada tabel diawah ini:

Angket yang telah diisi responden, diperiksa kelengkapan jawabannya kemudian disusun sesuai dengan kode responden. Kemudian mengkuantitatifkan pernyataan dengan memberi skor sesuai dengan bobot yaitu menggunakan skor 5,4,3,2,1 dan selanjutnya menghitung presentase tiap sub variabel dengan rumus:

\section{$\%$ : Jumlah skor tiap variable $\times 100 \%$ Jumlah skor maksimum}

\section{HASIL DAN PEMBAHASAN}

Pengembangan media pembelajaran prezi pada mata pelajaran membuat pola dilakukan berdasarkan tahapan sebagaimana yang terdapat dalam prosedur. Dilakukan proses awal penelitian yaitu dengan mengetahui potensi yang dapat didaya gunakan dan mengetahui masalah yang ditinjau lalu melakukan pengumpulan datadata pembuatan dan analisis kebutuhan siswa dan guru dengan sebaran angket yang telah ditentukan sesuai yang ditujukan dengan 
penrnyataan-pernyataan angket beserta skor penilaian yang ditentukan yaitu 5-1 dimana siswa menyatakan $87,00 \%$ dan guru $85,41 \%$ menyatakan sangat setuju bahwa media pembelajaran sangat dibutuhkan serta pengolahan media dengan menggunakan aplikasi prezi. Pada hasil angket yang disampaikan ahli materi pembelajaran dengan skor angket 5-1 memberikan tanggapan dengan presentase $83 \%$ dengan kriteria baik, bahwa materi layak digunakan karena telah memuat materi dan kriteria penyampaian yang memenuhi standart penyampaian pesan kepada siswa. Sementara itu ahli media pembelajaran memberikan tanggapan dengan presentase $87,14 \%$ dengan kriteria sangat baik layak digunakan karena telah didesain sedemikian rupa dan memenuhi standart media pembelajaran. Kemudian dilakukan uji coba lapangan yaitu uji coba kelompok kecil, uji coba kelompok sedang, uji coba kelompok besar. Pada hasil presentasi kelompok kecil yang disebarkan angket efektivitas media dengan skor 5-1 pada 5 siswa dengan nilai rata-rata 63,3\% dengan kriteria cukup. Pada hasil presentasi kelompok sedang yang disebarkan angket efektifitas media dengan skor 5-1 pada 12 siswa dengan nilai rata-rata $79,25 \%$ dengan kriteria setuju dan pada hasil presentasi uji coba kelompok besar/lapangan yang disebarkan angket efektivitas media dengan skor 5-1 pada 39 siswa dengan presentasi rata-rata $89,25 \%$ dengan kriteria sangat setuju. Untuk hasil efektifitas media terdapat hasil dengan presentase untuk efektifitas media oleh siswa memperoleh $89,25 \%$ dan efektifitas media oleh guru memperoleh 93,33\% dengan kriteria keduanya "sangat setuju" sehingga media pembeljaran prezi pada mata pelajaran membuat pola layak digunakan dalam pembelajaran dikelas.

\section{KESIMPULAN}

Berdasarkan rumusan, tujuan, hasil dan pembahasan penelitian pengembangan media pembelajaran prezi dapat disimpulkan sebagai berikut: (1) Pengembangan produk, Pada tahap ini disimpulkan bahwa media pembelajaran yang dikembangkan termasuk kedalam kategori sangat setuju/sangat baik dengan presentase hasil penilaian masing- masing ahli materi $83 \%$ sangat setuju/sangat baik, ahli media $87,14 \%$ sangat setuju/sangat baik, untuk hasil uji tahap pertama 63,3\%, hasil uji coba tahap kedua 79,25\%, dan uji coba lapangan $89,25 \%$, (2) Efektivitas produk, Pada tahap ini disimpulkan bahwa media pembelajaran prezi yang berbasis multimedia yang dikembangkan efektif digunakan sebagai media pembelajaran pada mata pembelajaran membuat pola untuk kelas X SMK Awal Karya Pembangan Galang. Berdasarkan hasil tanggapan siswa pada uji coba efektivitas yang dilakukan pada tahap uji coba lapangan diperoleh penilaian dengan kriteria sangat baik dengan presentase rata-rata $89,25 \%$ dan tanggapan guru dinilai sangat baik dengan presentase rata-rata $93,33 \%$.

\section{DAFTAR PUSTAKA}

Arif S. Sardiman, dkk. (2010). Media Pendidikan:

Pengembangan, Pengertian,

Pemanfaatannya. Jakarta: PT Raja Grafindo Persada.

Arsyad, Azhar. 2011. Media Pembelajaran. Jakarta: Rajawali Pers.

Arsyad, Azhar. 2013. Media Pembelajaran Edisi Revisi. Jakarta: Rajawali Pers.

Ernawati, dkk. 2008. Tata Busana Jilid 3.

Jakarta: Direktorat Pembinaan

Sekolah Menengah Kejuruan,

Direktorat Jenderal Manajemen

Pendidikan Dasar dan Menengah,

Departemen Pendidikan Nasional.

Daryanto. 2011. Media Pembelajaran.

Bandung: PT Sarana Tutorial Nurani Sejahtera.

Dedi Wahyudi. 2013. Pengembangan Multimedia Pembelajaran Interaktif Pendidikan Akhlak dengan Program Prezi (Studi di SMP Muhammadiyah 2 Mlati SlemanTahunAjaran 20132014). Penelitian Skripsi, tidak diterbitkan, UIN Sunan Kalijaga, Yogyakarta.

Harvey and Barringer. 2014. Prezi for Profesional. Allcow Trading Company Ltd.

Latifah, Imroatun. 2013. Aneka Pola Busana. Yogyakarta: PT Intan Sejati Klaten. 
Maswin. 2010. Arti dan Manfaat Media Pembelajaran. Maswins for Education. (Online) 2010. (Dikutip: 26 Juni 2016).

http://www.maswin.com/2010/07/arti-danmanfaat-media-pembelajaran-html.

Muliawan, Porrie. 2003. Konstruksi Pola Busana Wanita. Jakarta: PT BPK Gunung Mulia.

Mundir. 2013. Statistika Pendidikan. Yogyakarta: Puataka Pelajar.

Poespo, Goet. 2000. Aneka Lengan Baju dan Manset. Yogyakarta: Kanisius.

Pratiwi, dkk. 2001. Pola Dasar dan Pecah Pola Busana. Yogyakarta: Kanisius.

Putri Zakiyatul Jannah. 2014. Pengaruh Media Pembelajaran Zooming Presentation Terhadap Hasil Belajar Siswa Kelas X pada Konsep Suhu dan Kalor. Penelitian Skripsi, tidak diterbitkan, UIN Syarif Hidayatullah, Jakarta.
Riduwan. 2010. Skala Pengukuran VariabelVariabel Penelitian. Bandung: Alfabeta

Rusman. 2014. Model-Model Pembelajaran: Mengembangkan Profesionalisme Guru. Jakarta: Rajawali Pers.

Sanaky, Hujair AH. 2013. Media Pembelajaran Interaktif-Inovatif. Yogyakarta:

KAUKABA DIPANTARA.

Simon, dkk (2008). The Fhasion Designer's Directory of Shape and Style. Singapore: The Page One.

Sugiyono. 2014. Metode Penelitian Pendidikan. Bandung: Alfabeta.

Susilana dan Riyana. 2009. Media Pembelajaran. Bandung: CV Wacana Prima. 